\title{
The Environmental Effects of Tourism Development in Noushahr
}

\author{
Gholamreza Janbaz Ghobadi ${ }^{1}$, Mahin Shah Verdian ${ }^{2}$ \\ ${ }^{1}$ Islamic Azad University, Nour Branch, Nour, Iran \\ ${ }^{2}$ Geography and Tourism Planning, Islamic Azad University, Nour Branch, Nour, Iran \\ Email: gghobadi@yahoo.com,mahin.shahverdian@gmail.com
}

Received 15 June 2016; accepted 7 August 2016; published 11 August 2016

Copyright (C) 2016 by authors and Scientific Research Publishing Inc.

This work is licensed under the Creative Commons Attribution International License (CC BY). http://creativecommons.org/licenses/by/4.0/

\section{Abstract}

Tourism is considered as a potentially sustainable industry and plays a significant role in the development of the society at different levels and is seen as an important step to achieve sustainable development. The development of tourism in Noushahr has resulted in instability in terms of environmental aspects. Therefore, given that the process of tourism development in these regions would result in the destruction of the environment and cause many environmental problems as well as the undesirable and instable conditions, the present study aims to explore the environmental effects of the tourism development in Noushahr. To this end, a descriptive-analytic methodology is used to delve into aspects and indicators affecting the sustainable development in terms of environmental factors. In addition, the data are collected through documents and library and field methods. The population under study includes people living in Noushahr and tourists visiting it. The research sample includes 380 families and 384 tourists who were selected through the Cochrane formula. The collected data are analyzed using descriptive and inferential statistics including t-test. Results of the study show that there is a significant relationship between environmental effects and tourism. Besides, the level of negative effects caused by tourists in all cases under investigation is beyond the acceptable level in the view of the local community. As such, tourism should be developed in a way that while responding to tourists' leisure needs and improving their quality of experience it contributes to improving the quality of the environment.

\section{Keywords}

Environmental Analysis, Tourism, Tourism Development, Noushahr

\section{Introduction}

Tourism is seen as one of the greatest and most diverse industries in the world and its rapid growth has been followed with numerous social, economic, and environmental changes and thereby it has been turned into an 
important field of study among scholars. The tourism development is heavily dependent upon natural, cultural, and social environments. Therefore, maintaining or improving the quality of the environment is crucial for tourism purposes. Urban tourism, host-tourist interactions, and the production of tourist spaces for visiting urban areas with conflicting intentions, visiting attractions, and the use of facilities and services have various impacts on urban spaces and economy [1]. Noushahr as a port city with beautiful shores, good climatic conditions, and other natural attractions is one of the destinations for domestic and foreign tourists. Tourists vesting the shores of the city have caused some damages to shores, the environment, and tourist areas with their environmental consequences that have serious threatened the sustainable development in the city. On the other hand, today tourism has turned out to be an important economic domain for many urban managers and authorities, which requires assessing the competition arena, defining and setting goals, making judgment among different alternatives in terms of investment, logistics, and the creation of appropriate structures, and trading urban tourist products. When making decision in urban tourism planning, one must consider all effective factors and choose the best one from among them [2]. Now the most important point in planning based on attractions is how to prioritize these attractions in the development process and how to develop them. To measure and prioritize attractions, various criteria such as economic, sociocultural, infrastructural, environmental, institutional, legal, and geographical factors are often considered so that it is made possible to make decisions concerning various attractions [3]. Therefore, the analysis of environmental consequences resulting from the development of tourist activities in northern seashores especially in Noushahr seems essential. Among irreparable damages made by tourism to this city are pollutions from wastes, polluted waters of seashores and rivers, and changes in rural and urban landscapes and sceneries. The main objective of this study is to explore the environmental effects of tourism development in Noushahr and the impact of tourism on the environment of this city. Urban tourism, host-tourist interactions, and the production of tourist spaces for visiting urban areas with conflicting intentions, visiting attractions, and the use of facilities and services are related to the tourism industry and they have various impacts on urban spaces and economy [4]. In many tourism development projects, a part of the project activities is assigned to constructing hotels, inns, and accommodations, preparing infrastructural facilities such as the development of road networks, water and energy supply pipelines, constructing recreational establishments, and performing different human activities. Such activities in preparation and implementation stages require excavation and embankment, digging, ground leveling, drilling, cleanly shaving trees and plants, machinery and equipment shuttling, hedging, dredging, etc. Each of these activities results in soil erosion, reduced fertility, decreased water storage, changes in soil texture and structure, and increased density and mass weight. In addition to the above activities that are performed in the preparation and implementation stages, activities done in the operation stages as well as tourist activities in natural environments where there is less need for creating man-made environment may affect the soil conditions and properties. In order to depict the relationship between urban tourism, sustainability, and urban sustainable development based on a conceptual model, aspects and indicators of urban sustainable development are analyzed. The conceptual model combines three main components of development that are society (happy society), economy (prosperous society), and ecology (environment). Since combining these components aims to reach sustainable development, first the sustainability of each component must be established [5]. Environmental aspects of tourism are among areas that capture the attention of geographers. The reason behind this lies in the nature of geography with its strong approach to relations between human and the environment [6]. In fact, the impacts of tourism and recreational activities on the environment and the degeneration of resources are among issues shared by human and natural geographers when dealing with problems caused by tourism. The other reason is the mere significance of the natural environment for tourism and recreational activities [7]. Potential problems of environmental impacts of tourism are caused as these impacts often occur in a susceptible and vulnerable environment such as small islands, coastal areas, mountains, special desert areas, and ancient and historical places, because there places are more likely than other places to attract visitors and tourists. Environmental problems caused by tourism include the destruction of the environment as a result of constructing buildings or polluting the natural environment [6]. Evaluation (measurement) is a method or tool used to recognize the existing or possible effects of functions, activities, and projects. This definition is different from material valuation. Evaluation is a measure that seeks a basis to show the level of differences or gaps in certain qualities [5]. Environmental Impact Assessment (EIA) is a technique to measure or predict the impacts and consequences of implementing a project or operation on the environment so that given the conditions and the type of impacts, the project is implemented in a way that it has the minimal impact on the environment. The development of leisure and tourism activities in a given region creates numerous jobs and as a result many people may migrate to the region and its population increases, accordingly. Consequently, the number of small 
rented houses, automobile shooting galleries, restaurants, and shops increases. Besides, land price may go up and main and small roads are developed. As the number of these settlements and buildings increases, the extent of natural landscapes decreases and the number of man-made landscapes increases. The extent and type of environmental effects of tourism depends on the types and density of tourism development. Therefore, the effects of tourism must be investigated.

\section{Literature Review}

Lots of studies have assessed the environmental impacts of tourism. For instance, [8] explored the environmental impacts of tourism in coastal areas of Ramsar and found that the development of this type of tourism has caused many environmental problems, the most important of which include the destruction of vegetation, the pollution of coastal waters, and the destruction of the coastal landscape.

[7] investigated the intensity of the environmental instability of rural habitats using a multi-criteria model in 101 villages of 809 villages in Sistan and Balouchestan Province. Results showed that the environmental instability is low or moderate in $18.8 \%$ of the villages under study and serious and very serious in $81.2 \%$ of the sample villages. In another study, [6] explored the environmental effect of air pollution on tourism activities in Shiraz. Their results suggested that there are significant correlations between climatic parameters such as temperature, pressure, moisture, and rainfall and gaseous pollutants such as nitrogen dioxide, nitrogen monoxide, sculpture dioxide, and neutronoxide. Accordingly, the development of sound tourism plans requires paying close attention to air quality standards and climatic parameters.

[4] [5] assessed the environmental impact of coastal tourism on urban sustainable development in Tonekabon. They found that that coastal tourism has in fact a slight impact on urban sustainable development and sometimes it is considered as an environmental problem. The frequency of constructions in the coastal areas of Tonekabon beyond the land capacity has led to not only the excessive and improper horizontal development of the city but also the environmental pollutions and especially the pollution of water resources.

[8] examined the impact of tourism development on the marine environment in Chabahar Gulf. The results of his study showed that tourist wharfs in Kish Island are among the causes of the destruction of coral shores. In addition the construction of hotels and new recreational centers can result in increased wastewater and thus increased destruction of marine plants and reduced oxygen and faunal diversity.

[9] analyzed the relationship between coastal tourism development and its environmental impacts in coastal areas of Bandar Abbas. They found that tourism activities and its consequences in the environment requires attention, expertise, planning, and management to make it possible to for us to have a healthy and natural environment while benefiting from economic, cultural, and social advantages if a prosperous and profitable tourism.

In their study, [10] evaluated the environmental effects of the tourism industry in line with sustainable development in Abu Musa Island. Their results indicated that there is a positive significant relationship between the ecotourism in the island and sustainable development.

\section{Materials and Methods}

The present study is an applied and descriptive research concerning the type of research and a field study in terms of the method of data collection. Besides, this study is considered as a survey research with regard to the generalization of its findings. The population under study includes 43387 people living in Noushahr in 2011 (Statistical Center of Iran) of whom a total number of 380 heads of families were included in the research sample through the Cochrane formula and simple random sampling. In addition, based on the figures provided by Cultural Heritage and Tourism Organization of Mazandaran Province showing that approximately 5 million tourists visited the city in 2015, 384 tourists were included in the sample under study using the Cochrane formula. To assess the environmental impact of tourism development in Noushahr, a questionnaire with 9 components and 29 items was used to collect the data, as shown in Table 2. In addition, responses to the questionnaire items were scored using a likert scale. The collected data were analyzed by SPSS using t-test.

\section{Results}

\subsection{Land Resources}

Land resources underlay organizing the regional development. In other words, they are the main tool for making 
regional and national planning and decisions that facilitate environmental, economic, and social plans in each region and are used as the main tool for integrating environmental, economic, and social plans with physical and spatial plans. The results of data analysis are provided in Table 1 at the error level of 0.05 . According to tourists' opinions, there is a significant relationship between the environmental impacts and tourism development in Noushahr in terms of items related to the impact of tourism development on increased use of natural resources, increased constructions and the destruction of natural resources, and the development of constructions without management and planning $(\mathrm{P}<0.05)$. However, the results of the study concerning the destruction of natural landscapes, increased pressure, and increased tolerance capacity of natural resources indicate that tourism development has no impact on increased number of natural species, land use changes, and increased use of natural resources.

\subsection{Protecting Natural Heritage and Attractions}

Today as a consequence of the increased population in the world, problems such as excessive reduction of natural resources, increased pollution, and imbalanced distribution of resources have occurred. According to the respondents' views in this study, there is a significant relationship between tourism development and its environmental impact in Noushahr in terms of the lack of basic facilities per each tourist (access, restrooms, caterings, and parking spaces) $(\mathrm{P}<0.05)$. Besides, tourism development has increased the amount of waste materials produced by the tourism sector. However, there is no preventive measure by tourists to minimize solid and waste materials and increased recyclable wastes produced in tourist units (Table 2).

Table 1. Impact of tourism development on land resources.

\begin{tabular}{|c|c|c|c|c|c|c|c|c|c|}
\hline \multirow{2}{*}{ Items } & \multicolumn{5}{|c|}{$\begin{array}{l}\text { Likert scale }(1=\text { very high, } 2=\text { high, } \\
3=\text { moderate, } 4=\text { low, } 5=\text { very low })\end{array}$} & \multicolumn{4}{|c|}{ Results of t-test } \\
\hline & 1 & 2 & 3 & 4 & 5 & SD & $\begin{array}{l}\text { Equality of } \\
\text { variance }\end{array}$ & $\mathrm{N}$ & Result \\
\hline Destruction of natural landscapes & 119 & 121 & 368 & 69 & 87 & 0.263 & 1.258 & 764 & Not significant \\
\hline $\begin{array}{l}\text { Increase in excessive and uncontrolled } \\
\text { constructions }\end{array}$ & 129 & 216 & 297 & 61 & 61 & 0.174 & 1.851 & 764 & Not significant \\
\hline Increased pressure on natural resources & 300 & 153 & 152 & 65 & 94 & 0.004 & 8.355 & 764 & Significant \\
\hline $\begin{array}{l}\text { Impact of tourism development on increased } \\
\text { pressure of inhabitants in using resources }\end{array}$ & 178 & 137 & 243 & 64 & 142 & 0.000 & 40.96 & 764 & Significant \\
\hline Impact of tourism development on biodiversity & 149 & 144 & 293 & 63 & 115 & 0.106 & 2.618 & 764 & Not significant \\
\hline $\begin{array}{c}\text { Impact of tourism development on land use } \\
\text { change }\end{array}$ & 253 & 184 & 223 & 57 & 47 & 0.982 & 0.001 & 764 & Not significant \\
\hline $\begin{array}{c}\text { Impact of tourism development on destruction } \\
\text { of natural resources as a result of tourism } \\
\text { related constructions }\end{array}$ & 157 & 109 & 348 & 37 & 96 & 0.038 & 4.334 & 764 & Significant \\
\hline $\begin{array}{l}\text { Impact of tourism development on increased } \\
\text { pressure of inhabitants in using resources }\end{array}$ & 181 & 148 & 318 & 57 & 60 & 0.000 & 21.195 & 764 & Not significant \\
\hline
\end{tabular}

Table 2. Impact of tourism development on protecting natural heritage and attractions in Noushahr.

\begin{tabular}{|c|c|c|c|c|c|c|c|c|c|}
\hline \multirow{2}{*}{ Items } & \multicolumn{5}{|c|}{$\begin{array}{l}\text { Likert scale ( } 1 \text { = very high, } 2=\text { high, } \\
3 \text { = moderate, } 4=\text { low, } 5 \text { = very low) }\end{array}$} & \multicolumn{4}{|c|}{ Results of t-test } \\
\hline & 1 & 2 & 3 & 4 & 5 & SD & $\begin{array}{l}\text { Equality of } \\
\text { variance }\end{array}$ & $\mathrm{N}$ & Result \\
\hline $\begin{array}{l}\text { Basic facilities per each tourist (access, } \\
\text { restrooms, caterings, and parking spaces) }\end{array}$ & 170 & 154 & 228 & 84 & 128 & 0.000 & 19.885 & 764 & Significant \\
\hline $\begin{array}{l}\text { Increased amount of waste materials } \\
\text { produced by the tourism sector }\end{array}$ & 227 & 170 & 246 & 58 & 63 & 0.107 & 2.605 & 764 & Not significant \\
\hline $\begin{array}{l}\text { Preventive measure taken by tourists to } \\
\text { minimize solid and waste materials }\end{array}$ & 188 & 170 & 316 & 45 & 45 & 0.408 & 0.408 & 764 & Not significant \\
\hline $\begin{array}{l}\text { Increased recyclable wastes produced in tourist } \\
\text { units }\end{array}$ & 162 & 162 & 302 & 108 & 40 & 0.087 & 0.087 & 764 & Not significant \\
\hline
\end{tabular}




\subsection{Waste and Wastewater Production and Management}

Tourist activities enhance to the effective management of waste and wastewater systems. This indirectly contributes to the environmental sustainable development. Surface and groundwater resources are affected seriously by the excessive use of these resources and the discharge of different types of wastewater in the nature. The development of tourism projects when there is no regular wastewater collection and treatment systems and even when wastewater does not directly enter water resources results in the underground running of wastewater in the direction of slopes and its collision with impenetrable layers and thus the raising of the water table and the pollution of groundwater resources. This in turn poses serious threats to buildings and establishments and endangers inhabitants' and visitors health, especially in coastal areas when these impacts are more serious (Table 3).

As it can be seen, there is a significant relationship between tourism development and its environmental impact in Noushahr in terms of the increased number of tourist accommodation units with environmental labels and preventive measures taken to minimize air pollution. However, no measures have been taken for increasing the number of tourist places equipped with wastewater collection and disposal systems, increasing the public awareness about tourists' protective measures, and increasing the number of wastewater management systems.

\subsection{Protecting Biodiversity and Vulnerable Ecosystems}

The protection of biodiversity and vulnerable ecosystems is a scale that can be used to measure the health of ecosystems, but it is by itself a function of environmental conditions. Sudden and sharp environmental changes often result in group extinctions. Ecosystem diversity is measured in relation to species and genetic diversity, because the boundary among ecosystems and communities are highly misleading. Ecosystem diversity refers to the diversity of habitats, life communities, ecosystems, and ecologic processes inside them. In each ecosystem, living organisms affect each other and interact with the climatic conditions and surrounding soil. Ecosystems become more complex in the presence of human beings and they become substantially different from the natural ecosystem. Culture is a distinctive factor that makes up the human ecosystem. The human contact with the nature that is formed in a group and social from adds a social aspect to it. The more organized and informative this social aspect, the less will be social harms from changes made by humans in their surrounding environments and natural and environmental harms and the greater will be their achievements. Accordingly, as it can be in Table 4, there is no significant relationship between tourism development and its environmental impact in Noushahr in terms of attitudes towards waste disposal, controlling visitors concerning the observation of environmental regulations, and making legislations to protect rare species.

\subsection{Improving Public Awareness}

One of the main presumptions in environmental studies is that most environmental problems can be solved by increasing the public awareness about the environment. In other words, it is assumed that the environmental awareness is the key to solving most of environmental problems. The acquisition of the environmental awareness is the first step taken to achieve sustainability and basically the precondition for the human survival in the

Table 3. Impact of tourism development on waste and wastewater production and management in Noushahr.

\begin{tabular}{|c|c|c|c|c|c|c|c|c|c|}
\hline \multirow{2}{*}{ Items } & \multicolumn{5}{|c|}{$\begin{array}{l}\text { Likert scale ( } 1 \text { = very high, } 2=\text { high, } \\
3=\text { moderate, } 4=\text { low, } 5=\text { very low })\end{array}$} & \multicolumn{4}{|c|}{ Results of t-test } \\
\hline & 1 & 2 & 3 & 4 & 5 & $\mathrm{SD}$ & $\begin{array}{l}\text { Equality of } \\
\text { variance }\end{array}$ & $\mathrm{N}$ & Result \\
\hline $\begin{array}{l}\text { Increased number of tourist accommodation } \\
\text { units with environmental labels }\end{array}$ & 117 & 153 & 318 & 112 & 64 & 0.000 & 26.936 & 764 & Significant \\
\hline $\begin{array}{l}\text { Preventive measures taken to minimize air } \\
\text { pollution }\end{array}$ & 35 & 104 & 275 & 186 & 164 & 0.000 & 20.54 & 764 & Significant \\
\hline $\begin{array}{l}\text { Increased number of tourist places having } \\
\text { wastewater collection and disposal systems }\end{array}$ & 140 & 187 & 229 & 146 & 62 & 0.065 & 3.419 & 764 & Not significant \\
\hline $\begin{array}{l}\text { Increasing the public awareness about } \\
\text { tourists’ protective measures }\end{array}$ & 79 & 154 & 229 & 142 & 160 & 0.217 & 1.531 & 764 & Not significant \\
\hline Increased wastewater management systems & 39 & 135 & 353 & 134 & 103 & 0.288 & 0.020 & 764 & Not significant \\
\hline
\end{tabular}


Table 4. Impact of tourism development on protecting environmental and biodiversity and vulnerable ecosystems in Noushahr.

\begin{tabular}{|c|c|c|c|c|c|c|c|c|c|}
\hline \multirow{2}{*}{ Items } & \multicolumn{5}{|c|}{$\begin{array}{l}\text { Likert scale }(1=\text { very high, } 2=\text { high, } \\
3=\text { moderate, } 4=\text { low, } 5=\text { very low })\end{array}$} & \multicolumn{4}{|c|}{ Results of t-test } \\
\hline & 1 & 2 & 3 & 4 & 5 & SD & $\begin{array}{l}\text { Equality of } \\
\text { variance }\end{array}$ & $\mathrm{N}$ & Result \\
\hline $\begin{array}{l}\text { Number of management plans to control } \\
\text { visitors and assessment and monitoring } \\
\text { measures, and environmental regulations }\end{array}$ & 80 & 131 & 357 & 98 & 98 & 0.328 & 0.960 & 764 & Not significant \\
\hline $\begin{array}{l}\text { Increased number of tourist places having } \\
\text { wastewater collection and disposal systems }\end{array}$ & 69 & 219 & 303 & 91 & 82 & 0.554 & 0.351 & 764 & Not significant \\
\hline $\begin{array}{c}\text { Considering and making plans for waste } \\
\text { disposal }\end{array}$ & 65 & 132 & 317 & 103 & 147 & 0.886 & 0.28 & 764 & Not significant \\
\hline
\end{tabular}

future, is to have environmental awareness, the ability to understand environment, and live based on such awareness. Consequently, as it can be in Table 5, there is no significant relationship between tourism development and its environmental impact in Noushahr in terms of raising the awareness of local people and the awareness of the local communities about protected regions. However, this relationship is significant concerning the tourism manages with environmental training and educations.

\subsection{Pollution}

In addition to its positive and negative economic and social consequences, tourism prosperity in each geographical region is associated with air, water, sound pollutions, waste accumulation, and environmental pollutions. If these pollutions continue to occur they may result in irreparable damages. In the modern era which is characterized by the fight against pollution, tourism compared to other industries is seen as an industry without severe pollution consequences. This means that the protection of the environment and natural attractions is closely related to tourism. In addition, one of the main issues discussed by experts in the field is the use of an approach to environmental and sustainable development (Table 6).

Today the close relationship between tourism and the environment and the significance of the environmental planning approach and sustainable development approach have increased the attention to these approaches. The Manila Declaration as the most comprehensive declaration in line with the goals of modern tourism has underlined the importance of natural and cultural resources in tourism and the necessity of using and protecting these resources in the local community and the tourism industry. Therefore, as it is shown in Table 5, there is no significant relationship between tourism development and its environmental impact in Noushahr in terms of soil pollution, water pollution, and air pollution. However, this relationship is significant concerning environmental pollution, waste accumulation, and sound pollution.

\section{Conclusions}

Noushahr as a tourist city uses tourism as a stable source of income and it is facing major environmental problems and issues in the process of tourism development, whose real manifestations are reflected in the destruction of natural attractions, pollution, resource depletion, tourist attractions, and crowdedness and overpopulation. This has led to unfavorable environmental conditions in a way that people living in the city are experiencing major environmental problems. On the other hand, Noushahr is suffering from many problems such as the lack of proper infrastructural facilities including camping and parking spaces and toilets. Furthermore, pollution, wastewater release in streets and passages, and the destruction of the environment have negatively affected the region. Accordingly, 6 components and 29 items were used in this study to assess the environmental impact of tourism development in Noushahr. Based on the results from field data it is suggested that in order to solve the existing problems and issues, practical plans and policies must be revised and attention must be paid to the approaches and principles used to deal with the environmental effects of tourism development in Noushahr:

- A tourism policy-making council including representative from organizations such as municipality, natural resources, the environment, document registration, deputy of governorship planning, transportation department, governorship, cultural heritage, Islamic culture and guidance should be organized so that it can develop goals, strategies, and programs for the sustainable development of Noushahr in an efficient way. 
Table 5. Impact of tourism development on increasing public awareness about the environment in Noushahr.

\begin{tabular}{|c|c|c|c|c|c|c|c|c|c|}
\hline \multirow{2}{*}{ Items } & \multicolumn{5}{|c|}{$\begin{array}{l}\text { Likert scale ( } 1=\text { very high, } 2=\text { high, } \\
3=\text { moderate, } 4=\text { low, } 5=\text { very low })\end{array}$} & \multicolumn{4}{|c|}{ Results of t-test } \\
\hline & 1 & 2 & 3 & 4 & 5 & SD & $\begin{array}{l}\text { Equality of } \\
\text { variance }\end{array}$ & $\mathrm{N}$ & Result \\
\hline $\begin{array}{l}\text { Number of measures taken to inform } \\
\text { local people about protective tourist } \\
\text { activities }\end{array}$ & 56 & 134 & 279 & 154 & 141 & 0.103 & 2.669 & 764 & Not significant \\
\hline $\begin{array}{c}\text { Tourism managers with environmental } \\
\text { training }\end{array}$ & 128 & 225 & 192 & 162 & 57 & 0.000 & 14.566 & 764 & Significant \\
\hline $\begin{array}{c}\text { Awareness of the local community about } \\
\text { protected places }\end{array}$ & 147 & 290 & 204 & 85 & 38 & 0.169 & 1.893 & 764 & Not significant \\
\hline
\end{tabular}

Table 6. Impact of tourism development on pollution in Noushahr.

\begin{tabular}{|c|c|c|c|c|c|c|c|c|c|}
\hline \multirow{2}{*}{ Items } & \multicolumn{5}{|c|}{$\begin{array}{l}\text { Likert scale ( } 1 \text { = very high, } 2=\text { high, } 3=\text { moderate, } \\
\qquad 4=\text { low, } 5=\text { very low })\end{array}$} & \multicolumn{4}{|c|}{ Results of t-test } \\
\hline & 1 & 2 & 3 & 4 & 5 & SD & $\begin{array}{l}\text { Equality of } \\
\text { variance }\end{array}$ & $\mathrm{N}$ & Result \\
\hline Soil pollution & 188 & 242 & 160 & 101 & 73 & 0.073 & 3.23 & 764 & Not significant \\
\hline Water pollution & 255 & 190 & 141 & 122 & 56 & 0.054 & 3.73 & 764 & Not significant \\
\hline Sound pollution & 178 & 181 & 155 & 159 & 91 & 0.010 & 6.64 & 764 & Significant \\
\hline Waste accumulation & 234 & 169 & 189 & 119 & 53 & 0.000 & 0.018 & 764 & Significant \\
\hline Air pollution & 230 & 224 & 188 & 92 & 130 & 0.106 & 0.000 & 764 & Not significant \\
\hline Environmental pollution & 240 & 147 & 197 & 134 & 46 & 0.002 & 0.320 & 764 & Significant \\
\hline
\end{tabular}

- The efforts and commitment among tourism managers should be increased in order to support and protect the environment and encourage investors in the public and private sectors in making investments to protect the environment and set up urban sustainable tourists units with the aim of monitoring the implantation of tourism projects and surveying their environmental effects in line with policies and regulations in the field of tourism under supervision of Cultural Heritage, Handcrafts, and Tourism Organization.

- Policies for community-based tourism should be adopted by the public sector (Cultural Heritage, Handcrafts, and Tourism Organization) to promote the active participation of the local community in protecting the environment in the process of sustainable tourism development.

- The seasonal camps should be established in Noushahr to accommodate tourists in areas with tourist attractions and prevent sporadic and unsystematic settlement of tourists and visitors in the nature including beach platforms and the reward and punishment policies should be implemented to minimize the negative effects of activities associated with the environment, which requires the ongoing supervision of related authorities.

- Any plan to develop tourism and protect the environment in Noushahr based on its potential must take into account environmental aspects and their consequences because if there is no environmental assessment and the provision of practical solutions for tourism development it is not possible to create an ideal prospect for the coastal areas in the region under study in the future.

\section{References}

[1] Alvani, M. and Dehdashti, S. (1994) Fundamentals of Tourism. Foundation for the Oppressed, Tehran.

[2] Eddington, G.I. (1975) Ecotourism, Ecology, Recreational Activities, and Tourism (Translated by E. Kahram). EPA Press, Germany.

[3] Papali Yazdi, M.H. and Saghayei, M. (2006) Tourism: Nature and Concepts. SAMT Publications, Tehran.

[4] Statistical Center of Iran (2011) Population and Housing Census.

[5] Andriotis, K. and Vaughan, R.D. (2003) Urban Residents Attitudes toward Tourism Development: The Case of Crete. Journal of Travel Research, 42, 172-175. http://dx.doi.org/10.1177/0047287503257488 
[6] Colin Michael Hall and Stephen Page (2002) The Geography of Tourism and Recreation: Environment, Place and Space. Routledge, Taylor \& Francis, London and New York.

[7] Mitchell, L.S. and Murphy, P.E. (1991) Geography and Tourism. Annals of Tourism Research, 18, 57-70. http://dx.doi.org/10.1016/0160-7383(91)90039-E

[8] Papali Yazdi, M.H. and Saghayei, M. (2007) Tourism: Nature and Concepts. 2nd Edition, SAMT Publications, Tehran.

[9] WTO (2001) International Cultural Tourism Charter, Managing Tourism at Place of Heritage Significance. World Tourism Organization Press, Mexico.

[10] Musa Kazimi Mohammadi, S.M. (2001) Sustainable Urban Development: Concepts and Approaches. Journal of Geographical Research, 62, 12-20.

\section{Submit or recommend next manuscript to SCIRP and we will provide best service for you:}

Accepting pre-submission inquiries through Email, Facebook, LinkedIn, Twitter, etc. A wide selection of journals (inclusive of 9 subjects, more than 200 journals)

Providing 24-hour high-quality service

User-friendly online submission system

Fair and swift peer-review system

Efficient typesetting and proofreading procedure

Display of the result of downloads and visits, as well as the number of cited articles

Maximum dissemination of your research work

Submit your manuscript at: http://papersubmission.scirp.org/ 